\section{An Introduction to Embryology}

By Prof. B. I. Balinsky. Pp. xiv +562 . (Philadelphia and London : W. B. Saunders Company, 1960.) $54 s$.

D R. BALINSKY has produced a most valuable text-book, in which he has, in his own words, "endeavoured to present embryology as a single science, in which the descriptive morphological approach and the experimental physiological approach are integrated. . . . The subject ... includes such topics as post-embryonic development, regenera. tion, metamorphosis and asexual reproduction. Lastly, I believe that embryology cannot be presented adequately without establishing some connection with genetics".

In the past fow years, two or three similar attempts have been made; for example, the outstanding "Entwicklungsphysiologie" of Alfred Kühn in 1955, and the collective work "Analysis of Development" edited by Willier, Weiss and Hamburger in the same year. Balinsky's work is, in the choice of subjects, illustrative material and interpretation, much more similar to the only other one-man English book of this kind, Waddington's "Principles of Embryology" of 1956. It is somewhat surprising to find that this work, unlike the other two, is not mentioned in the text or bibliography.

In spite of its very wide field, Balinsky's book gives a quite thorough treatment of the topics selected for discussion. The material is very up-todate, and plentiful references are given to recent contributions. The book is also well illustrated, with figures and diagrams chosen more for their relevance to recent physiological interests than to serve as mere morphological descriptions in the manner usual in the older embryological texts. The index is unfortunately rather inadequate. This is, however, a minor fault in a work which will be very useful as the most up-to-date general treatment of embryology as a unified science.

\section{Faune de France No. 63}

Coléoptères Scarabéides. Par Renaud Paulian. Deuxième édition, revue et augmentée. Pp. ii +298 . (Paris: Éditions Paul Lechevalier, 1959.) 5,500 francs.

$$
\mathrm{T}
$$
"HIS second edition of the "Faune de France" volume on scarabroid beetles has been increased in size by some 60 pages. Changes in comparison with the first edition, which was published in 1944, are almost entirely additions. These provide more detailed information on life-histories, variation, distribution and keys for the identification of larvæ, in so far as the larvæ are known. Eight new species and two new subspecies of scarabæoid beetles have been added to the list of French species since 1944, making a total of 261 species. This gives an indication of the wealth of the French fauna, for the corresponding number for tho British Tsles is 68 .

The work contains keys which permit complete identification down to species and varieties, and each species is described in detail with a summary of its biology and distribution so far as these are known. Experience with the first edition has shown that the keys work easily and that the figures are adequate. The indexes to predators and parasites and to host plants are a useful addition.
The author has made an attempt to use the infra. specific categories in a consistent and logical manner and to this end defines species, subspecies, race, form and aberration in the preface. The use of the term 'race' is confusing and as defined here is the equivalent of ecophenotype. Aberrations are defined as accidental variations, often unique. This being so, there seems little value in giving keys to enable them to be identified. These are, however, minor defects in a work which has proved its worth.

\section{E. B. Britton}

\section{Wild Animals of the British Isles}

A Guide to the Mammals, Reptiles and Batrachians of Wayside and Woodland. By Dr. Maurice Burton. (The Wayside and Woodland Series.) Pp. ix $+180+$ 111 plates. (London and New York: Frederick Warne and Co., Ltd., 1960.) 17s. 6d. net.

THIS is another beautifully bound book in the "Wayside and Woodland" Series, containing 48 excellent colour plates from photographs and 63 interesting black and white illustrations. It is the usual compact size, so would be suitable for carrying in the pocket on a ramble. In all, 58 species of amphibians, reptiles and mammals (excluding marine mammals) are included, whether as rare as the red deer, as localized as the wild cat, or as common as the house-mouse. Each is dealt with simply and in a straightforward manner, some at greater length than others. The various animals are described, each under its own name, in the following sections: insect-eaters, flying mammals, gnawing animals, flesh-eaters, hoofed animals, lizards, snakes and amphibians. These sections are preceded by a helpful introduction, and there is an index at the end of the book.

This would be a most useful addition to a school library. It would be invaluable to the young naturalist as the accounts are both clear and accurate, and would greatly assist identification. Many adults would also find this a pleasing book.

\section{B. J. G. MaItLand}

\section{Dangerous Marine Animals}

By Bruce W. Halstead. Pp. $x+146$. (Cambridge, Maryland : Cornell University Press; London: Putnam and Co., Ltd., 1959.) 4 dollars ; $30 s$.

W this semi-popular, well-illustrated handbook, Dr. Halstead gives an account of marine animals that bite, sting or are poisonous to eat. He states that "it is not the purpose of this manual to throw needless scares into the skin-diving populace, but rather to point out some known facts regarding dangerous marine organisms, and to show what to do about the situation, if worse comes to worse".

$\mathrm{He}$ describes and illustrates each organism (and where appropriate, the venomous apparatus), including also the latest information on medical aspects, treatment and prevention. He has cast his net wide, from coelenterates to marine reptiles and seals, and his handbook will be particularly useful to the aqualung diver, the biologist and the medical practitioner as the first compact guide to the subject.

Dr. Halstead appears to have listed all the important vertebrates, but among the invertebrates many dangerous creatures remain to be generally recognized. In the coelenterates, for example, the author identifies a total of eleven species (out of a total of 25 stingers 